\title{
The Influence of Cultural Competence on the Interpretations of Territorial Identities in European Capitals of Culture
}

\author{
Tuuli Lähdesmäki \\ Department of Art and Culture Studies, \\ Faculty of the Humanities, \\ University of Jyväskylä \\ P.O. box 35(A), \\ Jyväskylä FI 40014, Finland \\ E-mail: tuuli.k.lahdesmaki@jyu.fi
}

\begin{abstract}
The EU's cultural initiative 'the European Capital of Culture'(ECOC) includes high identity political aims. It requires the designated cities to introduce and foster local, regional, and European cultural identities. In addition, the cities have used the designation as an opportunity to promote national cultural identity. Audiences of the ECOC events recognize and interpret different kinds of representations of territorial cultural identities from what the cities have to offer in culture. However, the contents of these interpretations vary drastically in the ECOCs. The article discusses whether the competence of interpreting the representations of territorial cultural identities is related to some social determinants of the audiences. Based on a questionnaire study conducted in recent ECOCs-Pécs (Hungary), Tallinn (Estonia), and Turku (Finland) - the study indicates that, for example, education, source of livelihood, and active cultural participation impact the interpretations of the representations of territorial cultural identities.
\end{abstract}

Keywords: cultural capital, cultural competence, European Capital of Culture, interpretation, reception, representation, territorial cultural identity 


\section{Introduction}

During the recent decades, the EU has actively participated in the negotiations on territorial attachments and identities in Europe. Identity politics has become an increasingly important domain of the EU's cultural policies and the action of the European Commission (Stråth, 2002; Shore, 2000; 2004). The trajectory is manifested, for example, in the increase of EU civic and cultural programs and initiatives that focus on strengthening local, regional, and European identities, and in the establishment of financing tools directed to regional development and increasing European cohesion. One of the EU's longest-running cultural initiatives - with high identity political aims - is the annual designation of the European Capital of Culture (ECOC). Since 1985, the EU has designated cities as European Cities of Culture in order to bring to the fore the common culture and cultural diversity among European countries. In 1999, the initiative was given a regular legal base when it was transformed into a Community action of the European Parliament and the European Council and renamed the European Capital of Culture.

The establishment of the ECOC initiative in 1999 strengthened its identity political focus. Fostering and promoting local, regional, and European cultural identities were articulated as the EU's major ideological goal for the ECOC initiative. The fundamental political agenda of the initiative was to get the cities to present themselves and their culture as part of the common European culture - to present the local as European (Lähdesmäki, 2012). In the designated ECOCs, the cultural programs, plans, and promotional rhetoric have obeyed the ideological goals, criteria, and instructions set by the EU-even in detailbecause they form a prerequisite for the designation. Even though the policy rhetoric of the ECOC does not include the national scale, the cities have also used the designation as an opportunity to support, promote, and market national culture and its characteristics (Lähdesmäki, 2011).

During their ECOC year, the designated cities organize hundreds of cultural events and performances that manifest, either directly or indirectly, diverse territorial cultural identities. These identities are fostered in the cities' official promotional rhetoric. The promotional rhetoric repeated, for example, in the media, in the form of advertisements, leaflets, information material, and opening speeches of the events, produces an identity political frame of interpretation that not only directs the implementation of the events but also has an influence on their reception. Case studies of the ECOC audiences indicate that the audiences have recognized and interpreted different kinds of manifestations 
of territorial cultural identities from what the ECOCs offer in cultural terms (Lähdesmäki, 2011; 2013a; Richards \& Rotariu, 2010). However, the contents of these interpretations vary drastically and the reasons for such variety in the interpretations have not yet been analyzed. Why do some people seem to be more able and competent to recognize representations of territorial cultural identities? Why is it easier for some people to explicate and describe their perceptions of territorial cultural identities? Is the ability and competence of perceiving and interpreting them related to some social determinants of the people? How do the interpretations of the representations of territorial cultural identities differ between people with different social background and cultural behavior?

This article focuses on the audience reception of the ECOC events in three cities: Pécs2010 (Hungary), Tallinn2011 (Estonia), and Turku2011 (Finland). Even though the cities differ greatly in their social, economic, cultural, and historical background, their ECOC programs followed the same policy guidelines determined by the EU. During their ECOC year, the cities aimed to promote and foster territorial cultural characteristics and identities. Various ECOC events in the cities focused more or less on bringing to the fore the characteristics of the city, region, nation, and/or Europe and the cultures of their people. The investigation of the audience's reception of representations of territorial cultural identities in the ECOC events is based on a questionnaire study implemented in the case cities. In order to answer the core questions regarding the social determinants in the interpretations of the representations of territorial cultural identities, the investigation adapts the discussions on diverse forms of 'capitals' - a conceptualization formulated by Pierre Bourdieu — and their impact on people's cultural competence, worldviews, and value systems. The article aims to investigate whether the same social determinants that, according to various sociological studies, influence people's cultural preferences and tastes also impact people's notions and interpretations of the representations of territorial cultural identities. Do the sociological views on cultural capital offer new insights for understanding people's notions on territorial cultural identities? 


\section{Territorial identities as fluid cultural constructions}

Contemporary studies of identity draw upon a wide range of theoretical conceptualizations. Various epistemological turns, such as the linguistic, narrative, and cultural turns that have characterized humanistic and social scientific studies during the last decades have also had an influence on the notions on identity in these fields. Scholars have emphasized identities as discursive, narrative, and cultural processes, in which identity is constantly being produced, varied, and altered in different expressions, representations, and performances (Hall S., 1990; 1992; Bauman, 1992; Bhabha, 1994; Bohlman, 2009). With the concept of cultural identity scholars have referred to common historical experiences and cultural codes, which are being repeated in communities through various myths, narratives, and symbols (Hall S., 1990; Giesen, 1991). Besides the emphasis on the experience of unity through these experiences and codes, the concept of cultural identity stresses the significance of distinctions for the construction of identities (Hall S., 1990). Cultural identities are created in a constant dialogue, negotiation, and contest of similarity and difference, sameness and distinction. The constructed and multilayered nature of cultural identity is a fundamental point of departure in understanding such phenomena. Cultural identities can be understood as processes taking various forms with respect to a particular time, place, and discourse (Hall S., 1990; 1992). Cultural phenomena are both manifestations of cultural identities and spaces of negotiations and contests where their contents and meanings are formed. In this article, locality, regionality, nationness, and Europeanness are understood as discursive cultural identities, which are represented and manifested in diverse cultural phenomena, texts, and cultural communication. Due to their discursive nature, the meanings of cultural identities and the interpretations of their representations vary among the people.

A city, a region, a nation, and a continent - in this case Europe - are often discussed and 'imagined' in relation to geography. All these entities have some kind of territorial shape- - boundaries that emerge and exist in various social practices, such as in culture, governance, politics, and economy, and that are instrumental in distinguishing them and their identities from others (Paasi, 2009a, p. 467). In political studies and human geography, the connections between collective sentiments and geography are often discussed together with the concept of territorial identity (e.g., Paasi, 1996b; 2000; Marks, 1999). The concept of territorial identity is used in recent studies on human geography in a loose way referring to diverse discursively formed and constructed communities and their representations. Thus, the territories which a city, a region, a nation, and 
Europe - and local, regional, national, and European cultural identities - refer to are profoundly abstract and fluid constructions crossing the administrative or fixed borders.

Several scholars have made a theoretical distinction between the collective territorial identity of the people living in a particular place and the collective interpretation of the identity of the place itself (Relph, 1976; Paasi, 2003; 2009b). In that case, the local identity of the people is considered to be formed by the people's awareness of the place or a region and its particular characteristics combined with a feeling of regional cohesion and togetherness amongst the inhabitants. The communality of the people is strongly linked to the real and imagined qualities of the places and the experiences of them. However, in practice the notions and sentiments of the collective territorial identity of the people and the identity of the place are intertwined in a number of ways (Paasi, 1996a, p. 209). In general, in the territorial identity building practices and discussions on them, the concepts of culture and identity seem to approach each other, so that identity is often seen as being manifested in culture and culture is considered to determine identities. A city, its physical and historical features, its citizenship, and activities of its inhabitants are intertwined in a multifaceted unity where the city's features also define the identity of its inhabitants. In turn, social networks give meanings to places. As Edward Said (1985, p. 54) has noticed, social and cultural identities are framed and given a background by anchoring them to particular places, landscapes, and environments. Territorial cultural identities are discursive constructions whose contents are flexible and which may be given diverse meanings depending on what defines them. The same spatial territory may function as an arena for multiple, even contradictory, notions of identities (e.g., Massey, 1995, pp. 67-68). According to the views of Zygmunt Bauman (1992) and Michel Maffesoli (1996), the basis of the formation of communal identities in contemporary culture lies in their expressive and performative nature. Similar ideas have also been applied in recent studies on the construction of territorial identities - the idea of performativity has been particularly emphasized by several scholars (Kuus, 2007; Kaiser \& Nikiforova, 2008; Prokkola, Zimmerbauer \& Jakola, 2012). In this article, language use is understood as a performative act that produces the objects people are describing and talking about.

Several researchers have discussed and theorized about different notions on territorial identities by describing these notions as 'thick' or 'thin' on the basis of their essentialistic or constructivist nature (e.g., Sack, 1997; Delanty, 2003; Axford, 2006; Davidson, 2008; Terlouw, 2012). Thick versions of identities are explained to appeal to the (real or imagined) shared features and qualities of the 
people. These shared features are often rooted in common culture, history, and habits or other concretized and historically narrated characteristics. As opposed to this, thin versions of identities are considered to be formed, for example, on the basis of legal rights, constitutions, citizenship statuses, or economic or administrative interests. Their nature is fluid, and they are grounded upon open and networked spatial form and project-like organization. Did the audiences in the case ECOCs perceive the territorial identities as 'thick' or 'thin'? Did some social determinants influence their perceptions on how territorial identities were manifested in the ECOC events? Before answering these questions, theoretical views on social structure and its impact on people's value systems and behavior are discussed more closely.

\section{Conceptualizing cultural capital}

Various sociologists have investigated the connections and the interdependence between social determinants - such as education, social class, and economic position - and the consumption of cultural products, the formation of tastes and attitudes, and the diverse lifestyle choices. An important source of inspiration for these studies has been Pierre Bourdieu's broad empirical investigations and theoretical formulations on social practices, power structures, and value systems. In the core of Bourdieu's theory is the identification of different forms of capital: the distinction between the economic and cultural capital forms the most powerful conceptual pair through which Bourdieu explains the formation and reproduction of social life. The content of economic capital refers to concrete assets of people, while the concept of cultural capital is more complex. Cultivated behavior, sophisticated social manners, and familiarity with cultural phenomena, arts, and the intellectual world are embodied forms of cultural capital which are internalized in the socialization process. Embodied cultural capital is required in order to obtain objectified cultural capital, that is, transmittable goods, such as books or works of art. The bases of the cultural capital may be inherited through the upbringing in a family in which cultural values are cherished. It may also be accumulated through the education or involvement in cultural or artistic spheres. One fundamental, and institutionalized, form of cultural capital is the educational capital obtained through certificated knowledge in the educational system (Bourdieu, 1984; 1987). Institutionalized cultural capital provides academic qualifications which create a "certificate of cultural competence which confers on its holder a conventional, constant, legally guaranteed value with respect to power" (Bourdieu, 1987, p. 248). 
Because the social conditions of the transmission and acquisition of cultural capital are less visible than those of economic capital, it is predisposed to function as symbolic capital; that is, to be unrecognized as capital and recognized as legitimate competence (Bourdieu, 1987). The concept of symbolic capital is discussed in Bourdieu's works alongside other forms of capital. Rather than perceiving it as a specific form of capital, it should be understood as a legitimate and generally recognized form of other capitals (Bourdieu, 1987). Any form of capital can be transformed as legitimate assets. Thus, symbolic capital embraces the idea of power.

Several researchers have applied the concept of cultural capital as an analytical tool in explaining the relations between educational background and diverse lifestyle choices, cultural consumption, and social trajectories (e.g., DiMaggio, 1987; DiMaggio \& Mohr, 1985; Lareau, 1987; Cookson \& Persell, 1985; de Graaf, 1986; Kalmijn \& Kraaykamp, 1996). The concept has been applied in various fields ranging from the studies of political attitudes (Lamont, 1987; DiMaggio, 1996) to investigations in religious commitments (Bradford, 2003). Cultural capital has also been noted as important for diverse identity projects, such as in the formation of intercultural or transnational identities (Trueba, 2009), or of a European identity (e.g., Farrell, 2010; Pöllmann, 2009). The broad interest in the concept during the past decades has resulted in diverse definitions and uses, and thus the concept has been given various and even contradictory meanings. Even in Bourdieu's own works, the focus of the concept differs (Lamont \& Lareau, 1988, pp. 155-156).

Bourdieu's investigations on cultural values and the reception of cultural phenomena have indicated how the appreciation of art is related to educational background and cultural capital (Bourdieu \& Darbel, 1991; Bourdieu, 1984). In an early study on museum visitors, Bourdieu and his colleagues Alain Darbel and Dominique Schnapper divided their informants to those who approached works of art through an artistic code, and to those who approached them through a code of everyday life (Bourdieu \& Darbel, 1991, pp. 39, 71). The users of the artistic code were able to discuss the works in relation to their style, form, genre, and artistic expression while the users of the code of everyday life categorized and perceived the works in relation to objects and phenomena in everyday life. The researchers related the codes to the social class structure: the users of the artistic code represented educated upper class while the users of the code of everyday life were part of the working class. In Distinction, Bourdieu developed the theory of reception codes further. He continued to explain the reception of art through the distinction between symbolic or poetic and reality-based understanding of the functions of art, but 
in Distinction emotions and knowledge were intertwined to explain different modes of reception. According to Bourdieu (1984, pp. 30-62), emotions and emotional interpretations are related to the use of the code of everyday life, while the use of artistic code requires aesthetic distance and knowledge of art. Would the same mechanism operate in the interpretation of representations of territorial cultural identities?

In Bourdieu's theory, social classes are based on an individual's location in the social space and the relations and distances between these locations rather than on the individuals' personal features. According to him, social classes are 'only' theoretical formulations (Bourdieu, 1991, pp. 231-232) and their formation inevitably includes the problematic of classification and definition (Bourdieu, 1998, pp. 10-12). Due to this, Bourdieu's theoretical views have faced a lot of criticism. Especially the emphasis on class has been considered old-fashioned in the contemporary, post-modern culture and the late-modern society in which individualization has often been said to weaken the class-based structures of lifestyle choices and social trajectories (see, e.g., Beck, 1992). The hierarchical structure of tastes and value systems related to the distinction of 'high', 'low', and 'popular' culture has been considered as transformed and blurred in the postmodern culture and replaced by pluralist taste systems. Since the end of the $20^{\text {th }}$ century, as the critics claim, the cultural differences have been increasingly difficult to explain with social class structure (Fornäs, 1995, p. 128; Hall J., 1992). Several scholars oriented in the postmodern thinking have emphasized how tastes and lifestyle choices are not tied to education, social class, or any type of symbolic capital, but are voluntary choices through which individuals produce their self-image and identity (e.g., Bauman, 1992).

The transformation and blurring of the borders of class-based cultural practices in contemporary culture does not, however, mean that all cultural hierarchies or cultural distinctions have vanished (Fornäs, 1995, p. 121). Several researchers (e.g., Bennett, Emmison \& Frow, 1999; Bennett et al., 2008; Pieur, Rosenlund \& Skjott-Larsen, 2008; Rosenlund, 2009; Purhonen, Gronow, \& Rahkonen, 2011; Purhonen \& Wright, 2013) have tested Bourdieu's theoretical apparatus in more recent societal conditions and noted how the societies, cultures, lifestyles, and tastes are still structured through a complex matrix of different types of symbolic capital, even though the cultural changes and increased global flows have in some cases complicated and transformed certain cultural and social practices.

The concepts of culture and identity are closely related-identities are represented in and through cultural products and phenomena. Thus, one could predict that cultural competence and cultural capital in general have an impact 
on how representations of cultural identities are recognized, perceived, and interpreted. Some studies (e.g., Robertson, Smyth \& McIntosh, 2008; Antonsich \& Holland, 2012) have indicated how the social class structure and education are intertwined with the production and understanding of territorial attachments or territorial identities. For example, the statistical analysis by Marco Antonsich and Edward Holland (2012) on the Eurobarometer Survey results from the Western-European countries indicated that the attachment to local, regional, and national scales decreased as the education of the respondents increased. In their investigation, the opposite was true for the European attachment, but without statistical significance. In addition, in wealthy regions the respondents were more likely to feel attachment to Europe, while in the poorer regions the respondents were more attached on the local and regional scales.

Bourdieu's investigations neither focus on the concept of identity nor discuss its bases as a social, cultural, or subjective practice. He does, however, discuss the social positions of subjects and the logic behind their diverse life choices. The importance of class status and its relation to a tapestry of diverse capitals is manifested in one of Bourdieu's core concepts - 'habitus'. It can be understood as socialized subjectivity - even though the agents in the social fields make subjective choices, their choices are, however, socially determined (Bourdieu, 1984, pp. 170-172). Various practices of living among a certain class or group are harmonized and homologized in accordance with its specific living conditions, but are not, however, mechanically determined to fulfil a certain social function or an individual 'need' (Sulkunen, 1982, p. 108.) Even though various scholars have criticized the concept of habitus for being overly-deterministic and unable to account for individual change, others have emphasized how it nevertheless recognizes the potential for change. This change is realized through movement across the social space which Bourdieu calls the 'field'. (Davey, 2009, p. 276)

Habitus is probably the most contested of Bourdieu's concepts, as Diane Reay (2004) notes. Its foundations contradict with the constructivist and post-modernist notions on identity. Nevertheless, Bourdieu's emphasis on the socialized subjectivity of habitus has also been used in discussions on identity in order to indicate the limits to reflexivity (Bottero, 2010). This aspect in the concept of habitus is taken as the point of departure (but not as a conceptual tool) (cf. Davey, 2009) in the analysis presented in this article: Identities are not expected to be only 'free' or 'voluntary' constructions, but the perceptions of them and the interpretations of their manifestations may be dependent on the social structure and some social determinants of the interpreters. 
In Bourdieu's theory, language and language use are intertwined with the social structure, mechanisms of distinction, and battle for profits and capital in the 'linguistic market' (Bourdieu, 1984, pp. 226-227; 1993, pp. 79-81). Education and cultural competence influence the ability to interpret and describe representations in art (Bourdieu \& Darbel, 1991). Thus, it can be assumed that the ability to describe the representations of territorial cultural identities would also relate to those social determinants that increase the cultural capital. In Bourdieu's work, language use is an integral part of habitus. Linguistic habitus refers not only to the habit of using the 'correct' language in a certain social situation, but also to the language use which is adapted to a certain linguistic market. Market directs the linguistic choices as people aim to speak in a way which is known to be legitimate in a certain field (Bourdieu, 1993). The impact of the linguistic market may, thus, have influenced the responses of the ECOC audience in the questionnaire study.

\section{Data and methods}

The questionnaire study on the ECOC audiences and their perceptions and interpretations on the territorial cultural identities was implemented in Pécs, Tallinn, and Turku during their ECOC years. Pécs, a city in southern Hungary with 157,000 inhabitants, was designated as the ECOC for 2010. The city, and the region around it, is known for its multiethnic population (many of the citizens being of German, Roma, Croatian, or Serbian backgrounds) and multiphased history, which has left its marks on the architecture and traditions of the area. Nowadays Pécs is an active academic centre and the cultural and artistic meeting point of a region surrounding it. Tallinn, the capital of Estonia, was designated as the ECOC for 2011 together with Turku. Tallinn is the largest city in Estonia with a population of 426,000 . The city is located on the northern coast of the country on the shore of the Baltic Sea. Today 52.5 per cent of the citizens of Tallinn define themselves as ethnic Estonians and 38.5 per cent as ethnic Russians. The multi-phased history of Tallinn, which includes being subjected to various rulers ever since the Middle Ages, has influenced the urban character of the city. The Soviet occupation has left its marks on both the uses of urban space and the cityscape of Tallinn. Turku, a city in southern Finland with a population of 180,000, was designated as the ECOC for 2011 together with Tallinn. As the oldest city in Finland, Turku has functioned as an arena for various social and cultural turning points in the Finnish national history. Nowadays Turku is a vibrant regional center. The location of the city on the shore of the Baltic Sea 
has had an impact on the history, the sources of livelihood, and culture of the inhabitants of the city and the surrounding region. Of the city's population, 5.3 per cent belong to the Swedish-speaking minority.

The questionnaire data was collected through self-completion questionnaires at 23 events in Pécs, 17 cultural events in Tallinn, and 21 events in Turku. The selected events differed greatly in their size, location, organization, target audience, and genre (including, e.g., traditional and contemporary visual art, environmental art, performance art, photography, opera, classical, experimental, ethnic, jazz, pop, folk and rock music, sound installation, film, folk, modern, partner and ethnic dance, theatre, mimics, puppetry, architecture, literature, handicraft, historical and ethnographic exhibitions, circus, and various communal events). Some of the selected events were festivals or series of events including various types of cultural and artistic performances. The aim of the selection was to include in the study an extensive range of events to represent the variety of the whole ECOC program in the case cities. In addition, the data includes the responses to an online study implemented in Pécs in 2010. A notice of the online questionnaire was sent to contact persons of ten local cultural organizations or networks representing various cultural fields. The contact persons were advised to inform their staff and stakeholders about the online questionnaire. The responses from the case cities (532 online and 200 paper responses from Pécs, 293 from Tallinn, and 400 from Turku) were combined for the analysis. Thus, the data includes altogether 1,425 responses. More detailed descriptions of the research design, the results of quantitative and qualitative analysis of answers in the case cities, differences between the answers, and the interpretations of the territorial cultural identities in the local and national contexts have been presented elsewhere (Lähdesmäki, 2011; 2013a, b).

In the questionnaire study, the concepts of territorial cultural identities were specified according to the name of the city, surrounding region, and the host country. In addition, the notions on Europeanness were investigated. In this article these territorial cultural identities are referred to as 'locality', 'regionality', 'national culture', and 'Europeanness'. The design of the questionnaire was based on the diverse and multifaceted meanings of the territorial cultural identities. The concepts were not explained or defined in the questions: the respondents were instructed to concretize and describe the concepts in responses to open questions according to their own understanding. However, the focus and the context of the study (i.e. cultural events and cultural representations) directed the respondents to perceive the territorial identities as cultural identities rather than, for example, understanding them in the sense of citizenship or as a civic status. 
The study included both closed and open questions on representations of territorial cultural identities. If the respondents considered in the closed questions that locality, regionality, national culture, and Europeanness were somehow represented in the ECOC events, they were asked to elaborate on their opinions in the open questions in more detail. In the analysis of the closed questions, the information about the respondents' educational level, source of livelihood, and habits of cultural consumption were statistically analyzed in relation to their opinions (on a Likert scale from 1 to 5) on whether locality, regionality, national culture, and Europeanness were represented in the ECOC events. The responses given to the open questions were analyzed in three phases.

Firstly, the variety of interpretations of the representations of locality, regionality, national culture, and Europeanness in the ECOC events was identified with a qualitative thematic analysis (Taylor \& Bogdan, 1984; Boyatzis, 1998; Zhang \& Wildemuth, 2009). The aim of the thematic analysis was to structure the "polyphonic" nature of the responses in order to understand how the representations of territorial cultural identities were interpreted in the ECOC events. As a result of the analysis, common themes and recurrent response types were identified: in the responses certain ways to interpret the representations of territorial cultural identities were more common than others. In the analysis, similar kinds of responses were arranged under a unifying theme.

Secondly, the found themes were quantified on the basis of their frequency in the open responses. The quantification of the themes was not based on individual respondents but the contents of their responses. Thus, a response from one respondent might comprise several ways to interpret the representations of territorial cultural identities.

Thirdly, the found themes were investigated in relation to the respondents' background information which indicates their engagement with the cultural capital. In the analysis these background factors were combined into a Cultural Competence Index, which was calculated for each thematic response. The index is based on tallying up the mean of the respondents' educational level on a scale of 1 to 7, the mean of the respondents' active participation in cultural events in general on a scale of 1 to 6 , the mean of the respondents' active participation in ECOC events on a scale of 1 to 5 , the percentage of the respondents involved in the production of the ECOC events, and the percentage of the respondents working in the art and cultural sector.

The creation of the Cultural Competence Index was inspired by the studies in which the quantity and quality of the cultural capital of the investigated 
people was measured. During the past decades, scholars have operationalized the concept in varying ways by combining those variables, which they believe will best explain and illustrate the researched topics. Variables have varied, for example, from taking dance lessons (Dumais, 2002) to the number of books owned (Lewicka, 2005). Bourdieu himself has argued that, ideally, cultural capital should be measured with an index combining items such as the educational level of one's parents and grandparents, the size of one's place of origin and residence, and the frequency of one's cultural activities (Bourdieu, 1974, p. 327). In Distinction, cultural capital is additionally discussed and measured through one's formal educational degree, knowledge and appreciation of artistic and cultural artefacts, consumption habits, lifestyle choices, and ethical values. In this study, the above-listed factors were considered as meaningful in explaining the influence of the social structure on the interpretations of representations of territorial cultural identities.

Bourdieu's theories on diverse capitals form a part of the broader theoretical apparatus he uses to explain various social practices, social relations, and social (re)production. The recognition of diverse capitals lays the ground, for example, to Bourdieu's field theory and views on the battle for distinction in the fields. The article utilizes Bourdieusian notions on social structure as a point of departure for the analysis and discussion of the audience reception of the ECOC events. As several scholars (e.g., Davey, 2009; Farrell, 2010; Lizardo, 2010) have noted, many of Bourdieu's concepts, such as cultural capital, habitus, and culture, are fluid, flexible, and vaguely defined, and therefore they are not used as analytical tools in the article. The Bourdieusian conceptualization in the article adopts a formulation which the author "could work with, rather than refer to" (cf. Davey, 2009, p. 277).

\section{The interpretations of the representations of territorial cultural identities}

\subsection{Analysis of the closed questions}

The statistical investigation of the questionnaire responses unsurprisingly indicated that the respondents who actively participated in cultural events in general (such as festivals, concerts, exhibitions, theatre plays) were also active in participating in the ECOC events (Cronbach's $\alpha$ 0.67). The correlation between the cultural participation and educational level (Cronbach's $\alpha 0.44)$ was not as strong, indicating only a moderate correlation (e.g., de Vaus, 2004, pp. 184). Even though the more educated respondents participated generally more often 
in different kinds of cultural events and visited the ECOC events organized in the city during the ECOC year more often than the less educated respondents, the lowest educational group in the study (comprehensive school or elementary school as the highest education) included a great number of respondents who were both very passive and very active visitors of the ECOC events. Particularly the free events in public spaces of the cities also attracted less educated audiences. The respondents who participated most often in cultural events worked in the art and cultural sector, expert services (e.g., offering academic and specialist services and consulting), and public administration. The respondents working in national defense, transportation, storing or guarding, and agriculture or other sectors of primary production participated least often in cultural events. The respondents in the same professions paid the most and the least visits to the ECOC events.

In the questionnaire the respondents were asked to evaluate on a Likert scale how in their opinion the ECOC events represented locality, regionality, national culture, and Europeanness. Statistical comparison revealed some differences between the respondents' opinions in different educational groups (comprehensive or vocational degree / matriculation, polytechnic or higher vocational degree / higher education degree). Locality, regionality, and national culture were perceived the most by the respondents with only a comprehensive or lower vocational education, while Europeanness was perceived the most by the respondents with a matriculation, polytechnic, or higher vocational degree; however, the differences were statistically significant only in the case of regionality $(\mathrm{p}=.000)$. In the case of Europeanness, the respondents with a doctoral degree perceived it more than any other group of respondents, while the respondents with only a comprehensive education perceived it the least $(p=.016)$. In general, the results indicate that education did not increase the perception of territorial cultural identities in the ECOC events-Europeanness being an exception, but the increase was non-linear.

When the respondents' opinions were investigated in relation to their source of livelihood, the results indicated that the respondents working in the primary production or physical work perceived the representations of locality, national culture, and Europeanness in the ECOC events less than the respondents working in service and clerical positions or expert professions, while the respondents in the expert professions perceived the representation of all the territorial cultural identities the most (Table 1). The results seem to contradict those that show the impact of the educational level on the perception of the territorial cultural identities. According to the responses, however, the educational level did not necessarily indicate a certain source of livelihood. Respondents with 
higher educational degree also worked in the primary production and physical duties, while lesser educated respondents could gain their living, for example, in expert services, education, or administration. The relatively young age of the respondents (mean age 34) may have influenced the contradicting results between the educational level and the source of livelihood: recently graduated respondents had necessarily not yet started their professional careers.

Table 1. Opinions on how the ECOC events represent the concepts of locality, regionality, national culture, and Europeanness according to the source of the livelihood of the respondents.

\begin{tabular}{|c|c|c|c|c|}
\hline & $\begin{array}{l}\text { Agriculture, forestry, } \\
\text { fishing industry, mining } \\
\text { / Industry / Construction } \\
\text { industry or electricity, } \\
\text { gas or water supply / } \\
\text { Transportation, storing } \\
\text { or guarding } \\
\quad(n=105)\end{array}$ & $\begin{array}{c}\text { Bulk or retail } \\
\text { trade / Nutrition or } \\
\text { accommodation / } \\
\text { Information technology, } \\
\text { communication or media } \\
\text { / Financing, insurance } \\
\text { or real estate / National } \\
\text { defense } \\
(n=241)\end{array}$ & $\begin{array}{l}\text { Medicine, health } \\
\text { care or social } \\
\text { services / Other } \\
\text { expert services } \\
\text { / Education / } \\
\text { Research / Public } \\
\text { administration / } \\
\text { Culture and art } \\
(n=779)\end{array}$ & $\begin{array}{l}\text { Kruskal- } \\
\text { Wallis test } \\
\text { Asymp. } \\
\text { Sig. }\end{array}$ \\
\hline Locality & $\underline{3.39}$ & 3.53 & 3.68 & $.005^{\star *}$ \\
\hline Regionality & 2.70 & 2.56 & 2.77 & $.023^{*}$ \\
\hline National culture & $\underline{3.49}$ & 3.62 & 3.74 & $.006^{* *}$ \\
\hline Europeanness & 3.56 & 3.74 & 3.77 & .147 \\
\hline
\end{tabular}

Note: Means on a scale of $1=$ very negative, $2=$ negative, $3=$ neutral, $4=$ positive, $5=$ very positive. The highest means are in bold, the lowest are underlined.

* $p<.05$

** $p<.01$

*** $p<.001$

\subsection{Analysis of the open questions}

In general, the education and the active participation in cultural events seemed to increase the competence to describe, in the open questions, the contents of the territorial cultural identities perceived in the ECOC events. The statistical analysis indicate that the more educated and more active participants of culture could recognize the representations of locality, regionality, and Europeanness more broadly and describe their notions about them in more diverse ways than the less educated and less active respondents (Tables $2 \& 3$ ). In the case of national culture the competence was more evenly distributed between the respondents 
regardless of their educational background or activity in cultural participation (Table 2). The increase in cultural activity did not correlate with the perception of national culture in the ECOC events (Table 3 ). Respondents working in primary production and physical duties recognized the representations of territorial cultural identities in the ECOC events the most poorly and their descriptions were the narrowest, while the respondents working in service and clerical positions provided the broadest descriptions, except in the case of regionality, which was the most broadly described by the respondents working in expert professions (Table 4). The differences between the responses of respondents working in service and clerical positions and expert professions were, however, slight. In general, locality was the most broadly and in the most diverse ways described by all respondents in their open responses. National culture was slightly more broadly described than Europeanness, while regionality was the least and the most narrowly described.

Table 2. Means of a number of different interpretations of territorial identities in the ECOC events given by the respondents belonging to different educational groups.

\begin{tabular}{|l|c|c|c|c|c|c|c|}
\hline & $\begin{array}{c}\mathrm{A} \\
(\mathrm{n}=45)\end{array}$ & $\begin{array}{c}\mathrm{B} \\
(\mathrm{n}=110)\end{array}$ & $\begin{array}{c}\mathrm{C} \\
(\mathrm{n}=462)\end{array}$ & $\begin{array}{c}\mathrm{D} \\
(\mathrm{n}=163)\end{array}$ & $\begin{array}{c}\mathrm{E} \\
(\mathrm{n}=251)\end{array}$ & $\begin{array}{c}\mathrm{F} \\
(\mathrm{n}=340)\end{array}$ & $\begin{array}{c}\mathrm{G} \\
(\mathrm{n}=36)\end{array}$ \\
\hline Locality & $\underline{0.62}$ & 0.65 & 0.80 & 0.90 & $\mathbf{1 . 5 5}$ & 1.10 & 1.39 \\
\hline Regionality & $\underline{\underline{0.09}}$ & 0.14 & 0.20 & 0.20 & 0.11 & 0.23 & $\mathbf{0 . 4 7}$ \\
\hline $\begin{array}{l}\text { National } \\
\text { culture }\end{array}$ & 0.62 & $\underline{0.44}$ & 0.65 & 0.70 & $\mathbf{0 . 8 3}$ & $\mathbf{0 . 8 3}$ & 0.58 \\
\hline $\begin{array}{l}\text { European- } \\
\text { ness }\end{array}$ & $\underline{0.40}$ & 0.47 & 0.59 & 0.60 & 0.64 & 0.70 & $\mathbf{0 . 8 1}$ \\
\hline
\end{tabular}

Note: $A=$ comprehensive or elementary school, $B=$ vocational course or degree or in-job training, $C=$ Matriculation examination, $D=$ Polytechnic or other higher vocational education, $E=B A$ degree, $F=M A$ degree, $G=P h D$ degree. The highest means are in bold, the lowest are underlined. 
Table 3. Means of a number of different interpretations of territorial identities in the ECOC events given by the respondents according to their activity in participating in cultural events.

\begin{tabular}{|l|c|c|c|c|c|c|}
\hline & $\begin{array}{c}\mathrm{A} \\
(\mathrm{n}=16)\end{array}$ & $\begin{array}{c}\mathrm{B} \\
(\mathrm{n}=53)\end{array}$ & $\begin{array}{c}\mathrm{C} \\
(\mathrm{n}=321)\end{array}$ & $\begin{array}{c}\mathrm{D} \\
(\mathrm{n}=244)\end{array}$ & $\begin{array}{c}\mathrm{E} \\
(\mathrm{n}=555)\end{array}$ & $\begin{array}{c}\mathrm{F} \\
(\mathrm{n}=209)\end{array}$ \\
\hline Locality & $\underline{0.19}$ & 0.30 & 0.68 & 0.94 & 1.00 & $\mathbf{1 . 1 9}$ \\
\hline Regionality & $\underline{0.00}$ & 0.09 & 0.13 & 0.14 & 0.23 & $\mathbf{0 . 2 5}$ \\
\hline $\begin{array}{l}\text { National } \\
\text { culture }\end{array}$ & $\underline{0.19}$ & 1.54 & 0.57 & 0.48 & 0.77 & 0.90 \\
\hline $\begin{array}{l}\text { European- } \\
\text { ness }\end{array}$ & $\underline{0.00}$ & 0.34 & 0.43 & 0.64 & 0.69 & $\mathbf{0 . 7 7}$ \\
\hline
\end{tabular}

Note: $A=$ hardly ever, $B=$ once a year or less, $C=$ a couple of times a year, $D=$ every other month, $E=1-3$ times a month, $F=$ once a week or more. The highest means are in bold, the lowest are underlined.

Table 4. Means of a number of different interpretations of territorial identities in the ECOC events given by the respondents according to their source of livelihood.

\begin{tabular}{|l|c|c|c|}
\hline & $\mathrm{A}(\mathrm{n}=105)$ & $\mathrm{B}(\mathrm{n}=241)$ & $\mathrm{C}(\mathrm{n}=779)$ \\
\hline Locality & $\underline{0.69}$ & $\mathbf{0 . 9 4}$ & 0.89 \\
\hline Regionality & $\underline{0.58}$ & 0.16 & $\mathbf{0 . 2 0}$ \\
\hline $\begin{array}{l}\text { National } \\
\text { culture }\end{array}$ & $\underline{0.45}$ & $\mathbf{0 . 7 4}$ & 0.69 \\
\hline $\begin{array}{l}\text { European- } \\
\text { ness }\end{array}$ & $\mathbf{0 . 6 5}$ & 0.60 \\
\hline
\end{tabular}

Note: $A$ = Agriculture, forestry, fishing industry, mining / Industry / Construction industry or electricity, gas or water supply / Transportation, storing or guarding, $B=$ Bulk or retail trade / Nutrition or accommodation / Information technology, communication or media / Financing, insurance or real estate / National defense, C = Medicine, health care or social services / Other expert services / Education / Research / Public administration / Culture and art. The highest means are in bold, the lowest are underlined.

The respondents interpreted and described the representation of locality, regionality, national culture, and Europeanness in the ECOC events in various ways in their open responses. The thematic variety of the interpretations (the common themes recurring in the data) ordered according to their Cultural Competence Index is presented in Table 5. A position in the top of the Table indicates thematic contents given by respondents with a high cultural competence (based on the index), while a position in the bottom of the Table indicates thematic contents given by the respondents with less competence. The thematic contents in 
the middle of the range indicate response types in which the respondents' cultural competence was on the mid-level, or which were given both by the highly or less competent respondents. The expressions 'high' and 'low' refer only to the positions in the range of the index and do not indicate any value ranking.

Table 5. The variety of thematic contents through which the respondents described the representation of locality, regionality, national culture, and Europeanness in the ECOC events ordered according to their Cultural Competence Index (CC-Index) based on the respondents' level of education, activity to participate in cultural events in general, activity to participate in the ECOC events, activity to participate in the organization of the ECOC events, and source of livelihood in the art and cultural sector.

\begin{tabular}{|c|c|c|c|c|}
\hline $\begin{array}{l}\text { CC- } \\
\text { Index }\end{array}$ & Locality & Regionality & National culture & Europeanness \\
\hline \multirow{15}{*}{ High } & Local arts & History & Venues & Present day \\
\hline & Cultural diversity & $\begin{array}{l}\text { Food and } \\
\text { products }\end{array}$ & $\begin{array}{c}\text { Natural } \\
\text { environment }\end{array}$ & $\begin{array}{c}\text { Connections to } \\
\text { Europe }\end{array}$ \\
\hline & Media & Regional arts & Present day & $\begin{array}{l}\text { Common } \\
\text { culture }\end{array}$ \\
\hline & $\begin{array}{c}\text { Natural } \\
\text { environment }\end{array}$ & Media & History & $\begin{array}{l}\text { Cultural } \\
\text { diversity }\end{array}$ \\
\hline & $\begin{array}{l}\text { Food and } \\
\text { products }\end{array}$ & Regional artists & Media & European arts \\
\hline & Local artists & $\begin{array}{l}\text { Regional } \\
\text { livelihood }\end{array}$ & Regular events & ECOC title \\
\hline & Tangible heritage & $\begin{array}{c}\text { Natural } \\
\text { environment }\end{array}$ & Tangible heritage & $\begin{array}{l}\text { Atmosphere / } \\
\text { Media }\end{array}$ \\
\hline & Cityscape & Venues & Cultural diversity & Foreign artists \\
\hline & Venues & $\begin{array}{l}\text { City represents } \\
\text { it }\end{array}$ & $\begin{array}{l}\text { City represents } \\
\text { national culture }\end{array}$ & Foreign visitors \\
\hline & Present day & $\begin{array}{l}\text { Cultural } \\
\text { diversity }\end{array}$ & $\begin{array}{c}\text { National } \\
\text { language(s) }\end{array}$ & Co-operation \\
\hline & History & $\begin{array}{l}\text { Traditional } \\
\text { culture }\end{array}$ & Atmosphere & $\begin{array}{l}\text { Display of } \\
\text { European } \\
\text { national } \\
\text { cultures }\end{array}$ \\
\hline & $\begin{array}{l}\text { Local citizens / } \\
\text { ECOC title }\end{array}$ & $\begin{array}{l}\text { Regional } \\
\text { citizens }\end{array}$ & $\begin{array}{l}\text { Food and } \\
\text { products }\end{array}$ & Quality \\
\hline & $\begin{array}{l}\text { Traditional } \\
\text { culture }\end{array}$ & Atmosphere & Citizens & Symbols \\
\hline & Atmosphere & & National arts & $\begin{array}{l}\text { Foreign } \\
\text { languages }\end{array}$ \\
\hline & Regular events & & $\begin{array}{l}\text { National artists } \\
\text { Traditional culture } \\
\text { Symbols }\end{array}$ & \\
\hline
\end{tabular}


According to the results, the respondents with high cultural competence interpreted the representation of locality and regionality by emphasizing the promotion of local and regional artistic projects, works of art, and performances at the ECOC events. In addition, interpreting the representations of Europeanness in the artistic projects demanded a relatively high cultural competence. As opposed to this, interpreting the representations of national culture in the artistic projects did not require as high a competence. It seems that the works of art and artistic projects are commonly (and among the people with less cultural capital) recognized as representations of national culture, while recognizing the works of art as representations of locality or regionality requires more special knowledge. Besides local arts, interpreting cultural diversity, multiculturalism or other kind of cultural pluralism as representations of locality required high cultural competence from the respondents. Thus, the less competent respondents perceived locality to be more uniform and coherent by stressing, for example, traditional local culture and cultural habits as being straightforward representations of it. Interpreting locality in the everyday or "background" phenomena of the ECOC events - such as environmental settings of the event venues and the host city, or local groceries, drinks, and locally manufactured products offered or sold at the events - was also typical for the respondents with high cultural competence.

Besides the new cultural projects and performances, the official ECOC programs in the case cities included several festivals and popular big events which had already been regularly organized in the cities for years. Interpreting locality by emphasizing these recurring festivals required the least cultural competence. Respectively, interpreting locality as a special atmosphere in the ECOC events required only low cultural competence. The descriptions of a special atmosphere of the cities were the most emotive way to interpret locality. In addition, the respondents with low competence could interpret locality at the ECOC events through the involvement of local citizens in the organization and arrangement of the events - and simply through emphasizing that the ECOC designation as such promotes representations of locality.

As in the case of locality, interpreting regionality through a special regional atmosphere or through the display of traditional regional culture in the ECOC events did not require high cultural competence. Also, the involvement of the people from the region in the ECOC events was interpreted as a manifestation of regionality by the respondents who had less cultural competence. Unlike in the cases of other territorial cultural identities, the respondents with low cultural competence often related regionality to the cultural diversity, multiculturalism, or other kind of cultural plurality they considered was represented at the events. It 
seems that regionality was easier to recognize as including diverse elements and cultural features than locality and national culture. In the case of Europeanness, interpreting it in terms of cultural diversity or multiculturalism required high cultural competence, but interpreting it as a display of distinct national cultures of different European nations was common among the respondents with low competence. As in the case of locality, perceiving typical regional groceries or products as representations of regionality demanded high cultural competence. Groceries and products were easier to relate to the representation of national culture. Recognizing local history seemed to require less cultural competence than recognizing regional or national history at the ECOC events. This may be due to the local historical focus of the various historical events in the ECOC programs in the case cities - local historical events were probably familiar to the ECOC audiences.

Interpreting the ECOC event venues and their environmental settings as representations of national culture and, thus, as having national importance demanded that the respondents have high cultural competence. Venues were easier to attach to locality and regionality. Interpreting different present-day phenomena and contemporary issues as representations of national culture demanded slightly more cultural competence than interpreting the display of history as a representation of national culture. The respondents with the least cultural competence interpreted the representations of national culture in the events most commonly through (nationally loaded) works of art and other artistic projects; (nationally defined) artists and performers involved in the events; traditional cultural features; and well-known national symbols. National symbols - such as national flags, colors, and coats of arms - and recurrent cultural traditions form the fundamental layer and primary imagery of the national cultural identity in the European societies, and, thus, recognizing and interpreting them as representations of national culture does not require any particular knowledge on culture.

The respondents with high cultural competence interpreted Europeanness at the ECOC events through various present-day phenomena and current issues which they recognized from the topics of the events. In addition, they could more often find Europeanness in various international connections they recognized between the host city, its cultural scene, and Europe, and in the cultural features they considered common to Europe. As opposed to this, it required less cultural competence to interpret Europeanness at the events through the display of different national cultures of European nations. In general, understanding Europeanness as a common and shared cultural identity based on common cultural grounds was relatively rare. Similarly, only a few-but profoundly 
culturally competent - respondents interpreted the display of historical issues as a representation of Europeanness at the events.

It required less cultural competence to interpret the presence of foreign languages at the ECOC events as a representation of Europeanness. In this case, the notions about Europeanness narrowed to an idea of multilingualism or, simply, to an encounter of different languages in situations in which the respondents did not face foreign languages as often. As in the case of national culture, respondents with low cultural competence commonly interpreted some recurrent European symbols or EU-related issues - such as European maps, the EU flag, euros, or European funding - as representations of Europeanness. In particular, the recognition of various EU symbols indicates that they have become everyday issues in European societies and that they are well internalized by the common people. In addition, the respondents with low cultural competence commonly related good quality, high standards, smooth organization, and 'order' to Europeanness. For them, Europeanness meant a positive standard in cultural matters to which the local, regional, or national cultural and artistic projects and their organization can be compared and which they should follow or try to reach.

\section{Discussion and conclusions}

Bourdieu argues that acquired cultural competences are used to legitimize social differences. Cultural competence is easily transformed into symbolic capital, which can be utilized as a means in the process of distinction and establishing one's social position or habitus. The competence of recognizing and interpreting the manifestations of territorial identities is also symbolic capital, even though it might be more difficult to transform into an asset. The responses in the data indicate, however, that respondents with high cultural competence were not only able but also willing to perceive and interested in perceiving cultural events as manifestations of territorial identities. This can be interpreted as an indication of an aim to distinguish oneself from the less culturally competent respondents. Even if this kind of symbolic capital is not easily transformed into an asset in the structures of Bourdieusian fields, it, however, has an important role in the production of the respondents' habitus.

Even though the territorial identities are commonly discussed in scholarly literature as discursive, narrative, cultural, and performative practices, studies have rarely deepened their investigation on these identities by analyzing the differences in the notions on them between people representing different social 
backgrounds. The results indicate that the social structure and the variables on which several scholars have focused in their analyses on 'cultural capital' had an impact on the perception and interpretation of territorial cultural identities in the reception of the ECOC events. The rise in the educational level and in the active participation in cultural events in general increased the diversity of the respondents' descriptions regarding their interpretations of the representations of territorial cultural identities. In addition, the respondents in higher social positions were able to describe their interpretations in more diverse ways. On the one hand, the results may indicate that the more culturally competent respondents were better able to recognize and were more familiar with the diverse representations of territorial cultural identities manifested in the cultural events. On the other hand, the results may indicate that these respondents were more competent and motivated to verbalize their notions and interpretations on territorial cultural identities. In light of the results, cultural competence and linguistic habitus seem to reinforce each other.

The respondents working in expert positions were more likely to consider that all investigated territorial cultural identities were represented at the ECOC events than the respondents gaining their livelihood from service and clerical positions or primary production and physical work. However, investigating the educational level of the respondents, the results indicate that increase in the educational level did not increase the recognition of representations of the territorial cultural identities, quite the contrary. In the case of Europeanness, the respondents with the highest educational level were, however, more likely to consider it represented at the ECOC events than any other group of respondents.

The study indicates that the respondents with low cultural competence often recognized and described territorial cultural identities as thick identities. Representations of locality, regionality, and national culture were, for example, commonly described through typical and well-known manifestations of cultural traditions, traditional cultural habits, and the involvement of the citizens of the local or regional community or the nation. In addition, respondents with low cultural competence often interpreted well-known works of art and artistic projects as representations of national culture. In general, these respondents usually described the representations of territorial cultural identities in fairly concrete terms: Recurrently organized local festivals or other big events were often described as representing locality, while the interpretations of national culture and Europeanness were often based on the recognition of common and well-known national or EU symbols and the encounter of national or foreign languages. Thus, the respondents with 
low cultural competence seemed to interpret the representations of cultural identities from the ECOC events by using what Bourdieu calls the "everyday life code'. In addition, the respondents with low cultural competence often related the representations of territorial cultural identities-particularly locality, regionality, and national culture - to a particular atmosphere or mentality by describing them in emotive terms.

The respondents with high cultural competence were able to describe the representations of territorial cultural identities in regards of their traditionality or novelty: that is, whether they thought that the ECOC events aimed to renew or rethink the predominant notions of territorial cultural identities or strengthen them. Their interpretations of cultural identities often relied on special knowledge of arts, cultural phenomena, or history. In addition, the respondents with high cultural competence often discussed the territorial cultural identities on a more conceptual level than the less competent respondents. Thus, the highly competent respondents often brought to the fore the discussions on diverse media representations and advertisement discourses on territorial cultural identities and how they were represented in them. The interpretation mode of the territorial cultural identities among the respondents with high cultural competence resembles the code Bourdieu calls 'artistic'. On the one hand, the results, thus, follow Bourdieu's views on the correspondence between cultural capital and cultural choices and notions. On the other hand, the results cannot simply be explained as reflecting the 'choice of the necessary', the 'cultural good-will', or the 'sense of distinction'-the terms Bourdieu (1984) has used in distinguishing the tastes and cultural choices of people belonging to different social classes.

Comparing the range of the Cultural Competence Index between the different thematic responses, the results indicate that the range was the smallest in the case of locality, the second smallest in the case of national culture, the second largest in the case of Europeanness, and the largest in the case of regionality. Compared to other territorial cultural identities, the respondents were the most unanimous about the representations of locality and the least so about regionality, which seemed to be the most abstract territorial scale and the most difficult territorial cultural identity to recognize and describe at the ECOC events.

In general, the results indicate that the representations of territorial cultural identities were broadly recognized at the ECOC events and diverse cultural, social, and environmental phenomena were interpreted as representations of them. Territorial cultural identities embody a vast range of meanings and their perception and interpretation are connected to various social determinants of the 
receivers. Territorial cultural identities are constantly negotiated in discursive, narrative, and cultural practices. Linguistic descriptions of them are performative acts producing the objects the people are describing and talking about.

Tuuli Lähdesmäki, PhD is researcher at the Department of Art and Culture Studies Faculty of the Humanities, University of Jyväskylä. Her current research project ("Identity politics in Pecs, Tallinn and Turku as European Capitals of Culture") is funded by the Academy of Finland. Her latest publication is 'Contested Identity Politics: Analysis of the EU Policy Objectives and the Local Reception of the European Capital of Culture Program' in The Baltic Journal of European Studies (2011, vol. 1, no. 2(10), pp. 134-166).

\section{References}

Antonsich, M. \& Holland, E. (2012), 'Territorial attachment in the age of globalization: The case of Western Europe,' European Urban and Regional Studies. Published online before print July 2012. http://dx.doi.org/10.1177/0969776412445830

Axford, B. (2006), "The dialectic of borders and networks in Europe: reviewing 'topological presuppositions'," Comparative European Politics, vol. 4, no. 2, pp. $160-182$.

Bauman, Z. (1992), Intimations of Postmodernity, Abingdon: Routledge.

Beck, U. (1992), Risk Society. Towards a New Modernity, London: Sage.

Bennett, T.; Emmison, M. \& Frow, J. (1999), Accounting for Tastes: Australian Everyday Cultures, Cambridge: Cambridge University Press.

Bennett, T.; Savage, M.; Bortolaia Silva, E.; Warde, A.; Gayo-Cal, M. \& Wright, D. (2008), Culture, Class, Distinction, London: Routledge.

Bhabba, H. (1994), The Location of Culture, London: Routledge.

Bohlman, P. (2009), Music, Nationalism, and the Making of a New Europe, London: Routledge.

Bottero, W. (2010), "Intersubjectivity and Bourdieusian Approaches to 'Identity'," Cultural Sociology, vol. 4, no. 1, pp. 3-22.

Bourdieu, P. (1974), 'The school as a conservative force: scholastic achievement and cultural inequalities,' in J. Eggleston (ed.) Contemporary Research in the Sociology of Education, London: Methuen, pp. 32-46.

Bourdieu, P. (1984), Distinction. A Social Critique of the Judgement of Taste, London: Routledge.

(1987), 'The forms of capital,' in J. G. Richardson (ed.) Handbook of Theory and Research of the Sociology of Education, New York: Greenwood Press, pp. 241-258. 
— (1991), Language and Symbolic Power, Cambridge, MA: Harvard University Press.

— (1993), Sociology in Question, London: Sage.

(1998), Practical Reason, Stanford: Stanford University Press.

Bourdieu, P. \& Darbel, A. (1991), The Love of Art: European Art Museums and Their Public, Cambridge: Polity Press.

Boyatzis, R. (1998), Transforming Qualitative Information: Thematic Analysis and Code Development, Thousand Oaks: Sage.

Bradford, V. (2003), 'Spiritual capital: Theorizing religion with Bourdieu against Bourdieu,' Sociological Theory, vol. 21, no. 2, pp. 150-174.

Cookson, P. \& Persell, C. (1985), Preparing for Power: America's Elite Boarding Schools, New York: Basic.

Davey, G. (2009), “Using Bourdieu's concept of habitus to explore narratives of transition," European Educational Research Journal, vol. 8, no. 2, pp. 276-284.

Davidson, A. C. (2008), "Through thick and thin: 'European identification' for a justified and legitimate European Union," Journal of Contemporary European Research, vol. 4, no. 1, pp. 32-47.

Delanty, G. (2003), 'Is There a European Identity?' Global Dialogue, vol. 5, no. 3-4. Retrieved from http://www.worlddialogue.org/content.php?id=269 [accessed 14 Mar 2014]

DiMaggio, P. (1987), 'Cultural capital and school success: The impact of status culture participation on grades of U.S. high school students,' American Sociological Review, vol. 47, no. 2, pp. 189-201.

(1996), 'Are art-museum visitors different from other people? The relationship between attendance and social and political attitudes in the United States,'Poetics, vol. 24, nos. 2-4, pp. 161-180.

DiMaggio, P. \& Mohr, J. (1985), 'Cultural capital, educational attainment, and marital election,' American Journal of Sociology, vol. 90, no. 6, pp. 1231-1261.

Dumais, S. (2002), 'Cultural capital, gender, and school success: The role of habitus,' Sociology of Education, vol. 75, no. 1, pp. 44-68.

Farrell, L. (2010), 'Pierre Bourdieu on European identity: Theories of habitus \& cultural capital,' Social and Political Review, vol. 20, pp. 107-115.

Fornäs, J. (1995), Cultural Theory \& Late Modernity, London: Sage.

de Graaf, P. (1986), 'The impact of financial and cultural resources on educational attainment in the Netherlands,' Sociology of Education, vol. 59, no. 4, pp. 237-246.

Giesen, B. (1991), Nationale Und Kulturelle Identitat: Studien Zur Entwicklung Des Kollektiven Bewusstseins in Der Neuzeit, Frankfurt: Suhrkamp.

Hall, J. (1992), 'The Capital(s) of culture: A nonholistic approach to status situations, class, gender, and ethnicity,' in M. Lamont \& M. Fournier (eds.) Cultivating Differences: Symbolic Boundaries and the Making of Inequality, Chicago: University of Chicago Press, pp. 257-285. 
Hall, S. (1990), 'Cultural identity and diaspora,' in J. Rutherford (ed.) Identity, Community, Culture, Difference, London: Lawrence \& Wishart, pp. 222-237.

— (1992), 'The question of cultural identity,' in S. Hall, D. Held \& T. McGrew (eds.) Modernity and Its Futures, Cambridge: Polity Press, pp. 273-325.

Kaiser, R. \& Nikiforova, E. (2008), 'The performativity of scale: the social construction of scale effects in Narva, Estonia,' Environment and Planning D: Society \& Space, vol. 26, pp. 537-562.

Kalmijn, M. \& Kraaykamp, G. (1996), 'Race, cultural capital, and schooling: An analysis of trends in the United States,' Sociology of Education, vol. 69, no. 1, pp. 22-34.

Kuus, M. (2007), 'Ubiquitous identities and elusive subjects: puzzles from Central Europe,' Transactions of the Institute of British Geographers, vol. 32, no. 1, pp. $90-101$.

Lähdesmäki, T. (2011), 'Contested identity politics: Analysis of the EU policy objectives and the local reception of the European Capital of Culture program,' Baltic Journal of European Studies, vol. 1, no. 2, pp. 134-166.

- (2012), 'Rhetoric of unity and cultural diversity in the making of European cultural identity,' International Journal of Cultural Policy, vol. 18, no. 1, pp. 59-75. (2013a), 'Interpretations of cultural identities in the European Capital of Culture events in Turku,' Ethnologia Fennica, vol. 40, pp. 66-88.

- (2013b), 'Identity politics of the European Capital of Culture initiative and the audience reception of cultural events compared,' The Nordic Journal of Cultural Policy, vol. 16, no. 2, pp. 340-365.

Lamont, M. (1987), 'Cultural capital and the political behavior of professionals and managers: a comment on Brint,' American Journal of Sociology, vol. 96, pp. 1501-1505.

Lamont, M. \& Lareau, A. (1988), 'Cultural capital: Allusions, gaps and glissandos in recent theoretical developments,' Sociological Theory, vol. 6, no. 2, pp. 153-168.

Lareau, A. (1987), Home Advantages: Social Class and Parental Interventions in Elementary Education, London: Falmer Press.

Lewicka, M. (2005), 'Ways to make people active: The role of place attachment, cultural capital, and neighborhood ties,' Journal of Environmental Psychology, vol. 25, no. 4, pp. 381-395.

Lizardo, O. (2010), 'Pierre Bourdieu as a post-cultural theorist,' Cultural Sociology, vol. 5 , no. 1, pp. 1-22.

Maffesoli, M. (1996), The Contemplation of the World: Figures of Community Style, Minnesota: Minnesota University Press.

Marks, G. (1999), 'Territorial identities in the European Union,' in J. J. Anderson (ed.) Regional Integration and Democracy. Expanding on the European Experience, Oxford: Rowman \& Littlefield Publishers, pp. 69-91. 
Massey, D. (1995), 'The conceptualization of place,' in D. Massey \& J. Pat (eds.) Place in the World, Oxford: Oxford University Press, pp. 45-86.

Paasi, A. (1996a), Territories, Boundaries and Consciousness. The Changing Geographies of the Finnish-Russian Border, Chichester: John Wiley and Sons.

— (1996b), 'Inclusion, exclusion and the construction of territorial identities: Boundaries in the globalizing geopolitical landscape,' Nordisk Samhällsgeografisk Tidskrift, vol. 23, pp. 6-23.

- (2000), 'Territorial identities as social constructions,' Hagar-International Social Science Review, vol. 1, no. 2, pp. 91-113.

- (2003), 'Region and place: Regional identity in question,' Progress in Human Geography, vol. 27, pp. 475-485.

- (2009a), 'Regions and regional dynamics,' in C. Rumford (ed.) The Sage Handbook of European Studies, London: Sage, pp. 464-484.

- (2009b), "The resurgence of the 'region' and 'regional identity'," Review of International Studies, vol. 35, pp. 121-146.

Prieur, A.; Rosenlund, L. \& Skjott-Larsen, J. (2008), 'Cultural capital today: A case study from Denmark', Poetics, vol. 36, no. 1, pp. 45-71.

Pöllmann, A. (2009), 'Formal education and intercultural capital: towards attachment beyond narrow ethno-national boundaries?' Educational Studies, vol. 35, no. 5, pp. 537-545.

Prokkola, E-K.; Zimmerbauer, K. \& Jakola, F. (2012), 'Performance of regional identity in the implementation of European cross-border initiatives,' European Urban and Regional Studies. Published online before print. http://dx.doi. org/0.1177/0969776412465629

Purhonen, S.; Gronow, J. \& Rahkonen, K. (2011), 'Highbrow culture in Finland: Knowledge, taste and participation,' Acta Sociologia, vol. 54, no. 4, pp. 385-02.

Purhonen, S. \& Wright D. (2013), 'Methodological issues in national-comparative research on cultural tastes: The case of cultural capital in the UK and Finland,' Cultural Sociology, vol. 7, no. 2, pp. 257-273.

Reay, D. (2004), "It's all becoming a habitus: beyond the habitual use of habitus in educational research," British Journal of Sociology of Education, vol. 25, no. 4, pp. 431-444.

Relph, E. (1976), Place and Placelessness, London: Pion.

Richards, G. \& Rotariu, I. (2010), '2007 European Cultural Capital in Sibiu Preliminary findings concerning the impact on major stakeholders,' Studies in Business and Economics, vol. 5, no. 1, pp. 146-155.

Robertson, D.; Smyth, J. \& McIntosh, I. (2008), Neighbourhood Identity. People, Time and Place, Layerthorpe: Joseph Rowntree Foundation.

Rosenlund, L. (2009), Exploring the City with Bourdieu: Applying Pierre Bourdieu's Theories and Methods to Study the Community, Saarbrücken: VDM. 
Sack, D. (1997), Homo Geographicus, Baltimore: The Johns Hopkins University Press.

Said, E. W. (1985), Orientalism, London: Penguin Books.

Shore, C. (2000), Building Europe: The Cultural Politics of European Integration, London: Routledge.

— (2004), 'Whither European citizenship? Eros and civilization revisited,' European Journal of Social Theory, vol. 7, no. 1, pp. 27-44.

Stråth, B. (2002), 'A European Identity: To the historical limits of a concept,' European Journal of Social Theory, vol. 5, no. 4, pp. 387-401.

Sulkunen, P. (1982), 'On the cultural sociology of Pierre Bourdieu,' Acta Sociologica, vol. 25, no. 2, pp. 103-115.

Taylor, S. J. \& Bogdan, R. (1984), Introduction to Qualitative Research Methods: The Search for Meanings, New York: John Wiley \& Sons.

Terlouw, K. (2012), 'From thick to thin regional identities?' GeoJournal, vol. 77, no. 5, pp. $707-721$.

Trueba, H. (2009), 'Multiple ethnic, racial, and cultural identities in action: From marginality to a new cultural capital in modern society,' Journal of Latinos and Education, vol. 1, no. 1, pp. 7-28.

de Vaus, D. (2004), Surveys in Social Research, London: Routledge.

Zhang, Y. \& Wildemuth, B. M. (2009), 'Qualitative analysis of content,' in B. M. Wildemuth (ed.) Applications of Social Research Methods to Questions in Information and Library Science, Westport: Libraries Unlimited, pp. 308-319. 